Papers and Proceedings of the Royal Society of Tasmania, Vol.109, 1975.

(ms. received 13.12 .1974 )

\title{
THE BASAL BEDS OF THE JUNEE GROUP
}

by A.V. Brown, N.J. Turner, and E. Williams

Geological Survey of Tasmania

\section{ABSTRACT}

The recent redescription by Corbett and Banks (1974) of the geology of Lewis 's type area of the Tyenna Valley for the Junee Group is commended. However, the introduction of correlations of rock sequences from localities over $24 \mathrm{~km}$ apart into a proposed definition of the Junee Group contravenes the Australian Code of Stratigraphic Nomenclature, and is therefore invalid. The correlations of the basal beds of the Junee Group discussed by Corbett and Banks are controversial.

\section{INTRODUCTION}

In his study of the geology of the Tyenna Valley, Lewis (1940) established conformable relationships between units of an extensive group of rocks which he termed the Junee Series. Lewis (p. 47-48) summarised the "sequence in the type area....

4. Diastrophic break.

3. Junee Series (iii) Blue Junee limestone.

(ii) Yellow mudstone containing trilobites and other fossils of lower ordovician age.

2. Probable unconformity".

(i) Quartzites with conglomerates and breccias interbedded.

Hills and Carey (1949, p. 24-28) referred to Lewis's sequence as the Junee Group which they defined in terms of rock units from widely dispersed localities in western and northern Tasmania. The use of the term "Junee Group" in a Tasmania-wide context is common practice (e.g. Banks 1962, p. 147), but members of the Geological Survey of Tasmania have long held the view that the type area of the Group is that of Lewis in the Tyenna Valley (e.g. Williams in Jennings et al. 1967, pp. 13-15), and have referred to correlates elsewhere as "Junee Group Correlates" (e.g. Williams and Turner 1974; Geological Atlas 1:250 000 series, in press; Williams, Solomon and Green in press\}.

In a recent paper Corbett and Banks (1974) redescribed the Junee Group in the type area of Lewis, and excluded from the Group Precambrian dolomite and quartzite sequences that had been clearly inadvertently incorporated by Lewis into his "Quartzites with conglomerates and breccias interbedded". At Tim Shea, Corbett and Banks (1974, p. 216) described Lewis's "Quartzites with conglomerates and breccias interbedded" as the Tim Shea Sandstone consisting of up to $300 \mathrm{~m}$ of shallow-water red to grey quartzose sandstone, minor conglomerate, red siltstone, and with dolomitic sandstone and locally derived breccia at the base unconformably on Precambrian dolomite.

\section{JUNEE GROUP CORRELATES}

In the Adam River Falls area, some $14 \mathrm{~km}$ to the west of Lewis's type area, Nye (1929, p. 10-11) described as one unit "several hundred feet at least.....conglomerates, grits and quartzites" which overlie unconformably "slates, cherts and finegrained breccia". Lewis (p. 49), although aware of the pitfalls of litho-stratigraphic correlations across 1 ittle known country, drew attention to the 'very close resemblance' between the quartz-rich rock unit with its geological relationships in 


\section{Basal Beds of Junee Group}

the Adam River Falls area and the Tim Shea quartz-rich sequence, and he postulated that his "Junee Series" extended from the type area into the Adam River Falls region.

In a current mapping programme of the Huntley Quadrangle the writers consider the shallow-water and terrestrial quartz-rich sequences of the Adam River Falls area to be associated in a single unit, as did Nye (1929, p. 11), although members of predominantly quartzose sandstone and predominantly quartzose conglomerate are being mapped separately, and they correlate the quartz-rich unit with the Tim Shea Sandstone. In contrast, Corbett and Banks (1974, fig. 1) correlated a transitional boundary between a lower quartzose sandstone member and an overlying predominantly quartzose conglomerate member within the single quartz-rich unit of Nye with the base of the Junee Group. Similarly, in the Reeds Peak area, some $24 \mathrm{~km}$ north-west of Lewis's type area, Corbett and Banks (1974, p. 214) excluded a lower shallow-water quartzose sandstone sequence from correlations made with the Junee Group of the type area, and correlate a transitional boundary between the lower quartzose sandstone sequence and an overlying predominantly quartzose conglomerate with the base of the Junee Group. Obviously, since the Tim Shea Sandstone has not been (or cannot be, see Corbett and Banks, p. 214 and fig. 1) 'walked' from Tim Shea to the Adam River Falls or Reeds Peak, there is an element of doubt in the correlations. Differences of opinion in correlations, however, obviously cannot affect what constitutes the Junee Group in Lewis's type area. Corbett and Banks (1974, fig. 2) recognise that their discussion of the sequences at Reeds Peak is in terms of correlations with rock units in Lewis's type area. However, it is most unfortunate that the rock successions of Reeds Peak and the suggested correlation with the Tim Shea Sandstone of Lewis's type area are considered by Corbett and Banks to be an essential part of their proposed redefinition of the Junee Group.

\section{DISCUSSION OF JUNEE GROUP DEFINITION}

Lewis's ordering of the litho-stratigraphic units in the Tyenna Valley is essentially correct, so that his "Junee" sequence can hardly be discarded, and his clearly stated intentions on its use must be respected. Presumably these comments are acceptable to Corbett and Banks since they have persisted in using the named "Junee" sequence. However, by the introduction of correlations with Reeds Peak successions into the formal definition of the Junee Group, Corbett and Banks appear to have acted contrary to the Code of Stratigraphic Nomenclature, with which they wish to accord (p. 214), for it states in Rule 12 "Rock unit names.....should be 'validated', by later workers in the some area........" (authors' italics), and in Rule 36 "The location of the type section of a valid unit may not be changed".

The present writers commend Corbett and Banks for their fine description of the geology of the Florentine Valley in south-west Tasmania and particularly for their redescription of Lewis's type area, but find invalid their introduction of correlations of rock sequences from localities over $24 \mathrm{~km}$ apart into the definition of the Junee Group. The invalidity of the proposed definition of Corbett and Banks cannot be changed by attempts to justify correlations. Furthermore, if correlations between the rock sequences at Reeds Peak and the Junee Group of Lewis's type area around Tyenna Valley are in any way controversial or unsatisfactory, the Australian Code of Stratigraphic Nomenclature allows for the creation of a new named group for the rocks of the Reeds Peak area. Hopefully, time-rock units of a fine enough scale will be estab1ished in the future which may he1p in determining more accurate 1ithostratigraphic correlations between the rock unit of Lewis's type area and rock sequences elsewhere. However, as indicated by Lewis (p. 48), it would be both pointless and unsupportable to attempt to force rock unit terms into a too precise compatibility with the accepted major international time-rock unit terms (e.g. Cambrian System, Ordovician System etc.).

\section{ACKNOWLEDGEMENTS}

This paper is published by permission of the Director, Tasmanian Department of 
Mines.

\section{REFERENCES}

Banks, M.R., 1962: Ordovician System, in Spry, A.H. and Banks, M.R. (ed.). THE GEOLOGY OF TASMANIA. J. geol. Soc. Aust. $9(2), 147-176$.

Corbett, K.D. and Banks, M.R., 1974: Ordovician stratigraphy of the Florentine Sync1inorium, southwest Tasmania. Pap. Proc. R. Soc. Tasm., 107, 207-238.

Hil1s, C.L, and Carey, S.W., 1949: Geology and mineral industry in Cerutty, L. (ed.) HANDBOOK FOR TASMANIA, $21-44$. ANZAAS, Hobart.

Lewis, A.N., 1940: Geology of the Tyenna Valley. Pap. Proc. R. Soc. Tasm., (1939), 33-59.

Nye, P.B., 1929: The osmiridium deposits of the Adamsfield district. BuZZ. geol. Surv. Tasm., 39 .

Williams, E., 1967: An outline of the geology of Tasmania, in Jennings, I.B., Noldart, A.J. and Williams, E. Geology and minera1 resources of Tasmania. Bulz. geol. Sum. Tasm. 50, 9-26.

and Turner, N.J., 1974: Geological atlas $1: 250000$ series. SK-55/3. Burnie. Explan. Rep. geol. Surv. Tasm. 16 pp.

Solomon, M. and Green, G.R. In press: The geological setting of metalliferous ore deposits in Tasmania, in Knight, C.L. (ed.). ECONOMIC GEOLOGY OF AUSTRALIA AND PAPUA NEW GUINEA. Australasian Institute of Mining and Meta1lurgy, Me1bourne. 